\title{
Peptide Domain Involved in the Interaction between Membrane Protein and Nucleocapsid Protein of SARS-associated Coronavirus
}

\author{
Xiaonan Fang, Linbai Ye*, Khalid Amine Timani, Shanshan Li, Yingchun Zen, \\ Meng Zhao, Hong Zheng and Zhenghui Wu \\ State Key Laboratory of Virology, College of Life Science, Wuhan University, Wuhan, Hubei 430072, China
}

Received 22 December 2004, Accepted 2 March 2005

\begin{abstract}
Severe acute respiratory syndrome (SARS) is an emerging infectious disease associated with a novel coronavirus $(\mathrm{CoV})$ that was identified and molecularly characterized in 2003. Previous studies on various coronaviruses indicate that protein-protein interactions amongst various coronavirus proteins are critical for viral assembly and morphogenesis. It is necessary to elucidate the molecular mechanism of SARS-CoV replication and rationalize the anti-SARS therapeutic intervention. In this study, we employed an in vitro GST pull-down assay to investigate the interaction between the membrane $(\mathrm{M})$ and the nucleocapsid $(\mathrm{N})$ proteins. Our results show that the interaction between the $\mathrm{M}$ and $\mathrm{N}$ proteins does take place in vitro. Moreover, we provide an evidence that 12 amino acids domain (194-205) in the $\mathrm{M}$ protein is responsible for binding to $\mathrm{N}$ protein. Our work will help shed light on the molecular mechanism of the virus assembly and provide valuable information pertaining to rationalization of future anti-viral strategies.
\end{abstract}

Keywords: Membrane protein, Nucleocapsid protein, Protein interaction and GST resin pull-down assay, SARS-CoV

\section{Introduction}

Severe acute respiratory syndrome (SARS), also called atypical pneumonia, is a human severe respiratory infectious disease that emerged recently in Asia, North America and Europe. A novel coronavirus named "SARS-associated coronavirus" (SARS-CoV) was recently identified as the causative agent of SARS (Drosten et al., 2003; Ksiazek et al., 2003; Peiris et al., 2003). Severe morbidity and mortality rate is up to $10 \%$ in the SARS-CoV infected patients (Lee et al.,

\footnotetext{
*To whom correspondence should be addressed.

Tel: 86-27-68752372; Fax: 86-27-68752372

E-mail address: linbaiye@whu.edu.cn
}

2003). The virions of the SARS-CoV are $80-140 \mathrm{~nm}$ in diameter, with projections surrounding the periphery (Ksiazek et al., 2003). The SARS-CoV is identified as positivestranded RNA viruse with approximately 29,727 nucleotides genomes packaged in helical nucleocapsids. The genome organization is similar to that other coronaviruses, where phylogenic analyses and sequence comparisons showed that the SARS-CoV is not closely resembled to any of previously characterized coronaviruses. There are four open reading frames (ORF) downstream of replicase (rep) that are predicted to encode the four structural proteins spike (S), envelope (E), membrane (M), and nucleocapsid $(\mathrm{N})$, which are common to all known coronaviruses. Besides, SARS-CoV also encodes several uncharacterized non-structural proteins (Marra et al., 2003; Rota et al., 2003).

The M protein of SARS-CoV consists of 221 amino acids in length and the amino acid sequence has low homology with $\mathrm{M}$ proteins of other members of coronaviruses. Based on the available information from other known coronaviruses, the 25 $\mathrm{kDa} \mathrm{M}$ protein is an important and the most abundant structural protein and can induce antibody-dependent complementmediated neutralization reaction (Woods et al., 1987). The M protein also plays a predominated role in the assembly of both naked and enveloped virus particles (Kuo and Masters, 2002). Research has demonstrated that the M protein contains highly conserved glycosylated sequences, and its glycosylation may be related to the interaction between virus and host cells (de Haan et al., 2002, 1998). In addition, the $M$ protein is characterized as having three domains; these include a short N-terminal ectodomain, a triple-spanning transmembrane domain, and a C-terminal endodomain (Armstrong et al., 1984).

The $\mathrm{N}$ protein of SARS-CoV is 422 amino acids in length, sharing only $20-30 \%$ homology with the $\mathrm{N}$ proteins of other members of coronaviruses. Based on the available information, the $\mathrm{N}$ protein is an extensively phosphorylated, highly basic structural protein, which is known to bind viral RNA to form the helical core structure (Davies et al., 1981). Several 
functions including viral packaging, viral core formation, and signal transduction have been attributed to the coronavirus nucleocapsid protein (Hiscox et al., 2001; He et al., 2003).

The protein-protein interaction between Coronaviridae $\mathrm{M}$ and $\mathrm{N}$ proteins has been reported in several in vitro studies on mouse hepatitis virus (MHV)(Narayanan and Makino, 2001; Kuo and Masters, 2002) and transmissible gastroenteritis virus (TGEV) (Escors et al., 2001). Although the interaction between $\mathrm{M}$ and $\mathrm{N}$ proteins of SARS-CoV has been observed in vivo, the amino acid sequence of the $\mathrm{M}$ protein involved in this viral protein-protein interaction has not been identified yet. It is undoubted that determination of $\mathrm{M}-\mathrm{N}$ interaction and identification of the amino acid sequences involved in this process will enlighten the molecular mechanism of the virus assembly which leads to future anti-viral strategies.

In this study, GST pull-down assay has been employed to investigate the interaction between the $\mathrm{N}$ and $\mathrm{M}$ proteins. As is expected, the interaction between the $\mathrm{N}$ and $\mathrm{M}$ proteins has been successfully observed in vitro and 12 amino acids peptide (194-205) in the C-terminal endodomain of M protein was found to be responsible for this interaction.

\section{Materials and methods}

Plasmid construction Plasmid pET-GST was used as a prokaryote expression vector for GST fusion proteins, and this vector introduces a GST-Tag and small hexahistidine-Tag at the Nterminus and the $\mathrm{C}$-terminus respectively, to facilitate subsequent purification. Truncated versions of $\mathrm{M}$ protein coding DNA fragments (M1, M2, M3, and M4) were obtained by polymerase chain reaction (PCR) using full length pGEM $^{\circledR}-\mathrm{T}-\mathrm{M}$ as a template (gifted from Dr. YingZhu, Wuhan university, Wuhan, China), and the target DNA fragments were cloned into pET-GST double digested with BamHI and EcoRI using standard cloning method, generating a $5^{\prime}$ oligonucleotide with an artificial BamHI site and an initiation codon and a 3' oligonucleotide with EcoRI site. The recombinant plasmids pET-GST-M1(90-221), pET-GST-M2 (90205), pET-GST-M3 (90-193) and pET-GST-M4 (90-180) were constructed using a pair set of primers, (M-F and M-R1), (M-F and M-R2), (M-F and M-R3) and (M-F and M-R4), respectively (Table-1) and transformed into DH5 $\alpha$ stains. Positive colonies were analyzed, confirmed by PCR and sequenced. Construction of pETHis-N recombinant plasmid for prokaryotic expression of SARS$\mathrm{CoV} \mathrm{N}$ protein was described previously (Timani et al., 2004).

Expression and purification of recombination protein The recombination plasmids were transformed into E. coli strains BL21
Table 1. Primers for $M$ gene sequential deletion

M-F ATGTGGGGATCCATGTGGCTTAGCTACTTC

M-R-1 GCCTGTGCTAGCGAATTCCTGTACTAGCAA AG

M-R-2 GCCATCGAATTCTAATTTATAGTTTCCAATACGGTAG

M-R-3 CTAATCGAATTCAGCAAAACCTGAATAGTGCC M-R-4 GCAGTCGAATTCTAATTTGTAATAAGAAAGCGTTC

Note: The restriction sites are underline; it is BamH1 in the forward primer and EcoR1 in the reverse primers.

(DE3). Protein expression was induced by addition of $1 \mathrm{mmol} / \mathrm{l}$ isopropyl- $\beta$-D-thiogalactopyranoside (IPTG) at $37^{\circ} \mathrm{C}$ for 3 hours. Cells were harvested by centrifugation and the pellet was suspended in binding buffer $(20 \mathrm{mM}$ Tris- $\mathrm{HCl} \mathrm{pH} 7.9,500 \mathrm{mM}$ $\mathrm{NaCl}, 5 \mathrm{mM}$ Imidazole, $1 \mathrm{mM} \mathrm{NaF}$, and $1 \mathrm{mM}$ PMSF), then sonicated and centrifuged at $12,000 \mathrm{~g}$ at $4^{\circ} \mathrm{C}$ for $30 \mathrm{~min}$. The clear supernatant was applied onto Ni-NTA affinity column (Qiagen, Chatsworth, USA) then washed with gradient washing buffers (20mM Tris-HCl pH7.9, $500 \mathrm{mM} \mathrm{NaCl}, 5,20,40,60,100 \mathrm{mM}$ Imidazole). Purified recombination protein was eluted with elution buffer $(20 \mathrm{mM}$ Tris- $\mathrm{HCl}$ pH 7.9, $500 \mathrm{mM} \mathrm{NaCl}, 200 \mathrm{mM}$ Imidazole) and concentrated by dialysis against polyethyleneglycol 6000 . The expression and purification of $\mathrm{N}$ protein were described previously (Timani et al., 2004).

GST pull-down assay Equal amounts (approximately $1 \mu \mathrm{g}$ ) of GST or GST fusion recombinant M proteins were immobilized on $20 \mu \mathrm{l}$ of GST resin, then incubated with 100ng of SARS-CoV N protein in GBT buffer $[10 \%$ glyceol, $50 \mathrm{mmol} / \mathrm{L}$ Hepes-NaOH $\mathrm{pH} 7.5,50 \mathrm{mmol} / \mathrm{L} \mathrm{KCl}, 715 \mathrm{mmol} / \mathrm{L} \mathrm{MgCl}_{2}, 0.1 \mathrm{mmol} / \mathrm{L}$ EDTA, $0.1 \mathrm{mmol} / \mathrm{L}$ dithiotreitol (DTT), $1 \%$ Triton $\times 100$ ] for $2 \mathrm{~h}$ at cold room $\left(4^{\circ} \mathrm{C}\right)$. After washing at least 4 times with GBT buffer, the bound proteins were eluted by heated at $100^{\circ} \mathrm{C}$ for $10 \mathrm{~min}$ with $2 \times$ SDS-PAGE disruption mix and were resolved by $12 \%$ SDSPAGE, then detected by Western blotting.

Western blotting The proteins were separated by SDS-PAGE and transferred to polyvinylidene difluoride membrane (PVDF) by standard methods. After blocking with PBST $(14 \mathrm{mmol} / \mathrm{L} \mathrm{NaCl}$, $2.7 \mathrm{mmol} / \mathrm{L} \mathrm{KCl}, 10 \mathrm{mmol} / \mathrm{L} \mathrm{NaHPO}_{4}, 1.8 \mathrm{mmol} / \mathrm{L} \mathrm{KH}_{2} \mathrm{PO}_{4}$ and $0.02 \%$ Tween-20) containing 5\% non-fat milk for $1 \mathrm{~h}$ at $4{ }^{\circ} \mathrm{C}$, the membrane was incubated for $2 \mathrm{~h}$ at room temperature with antiSARS-CoV N protein rabbit antibody (1: 750, unpublished data). After washing three times in an appropriate volume of PBST, the membrane was incubated for $1 \mathrm{~h}$ with peroxidase labeled goat antirabbit IgG ( $1: 5000$, Sigma, St. Louis, USA). The membrane was washed three times with PBST and once with distilled water, for 10 min each. Finally, the washed membrane was transferred into an

Table 2. The binding domain in the M protein as being responsible for the interaction with nucleocapsid protein. The numbers indicated the position of the first amino acids in the binding site sequences

\begin{tabular}{cll}
\hline & \multicolumn{1}{c}{ The binding site sequence } & Reference \\
\hline TGEV & 233-AYYVKSKAGDYSTEARTDNLSEQEK & Escors et al (2001) \\
MHV & 201-AVYVKSVGNYRLPSNKPSGADTAL & Kuo et al (2002) \\
SARS-CoV & 194-AYNRYRIGNYKL & Determined in this study \\
\hline
\end{tabular}




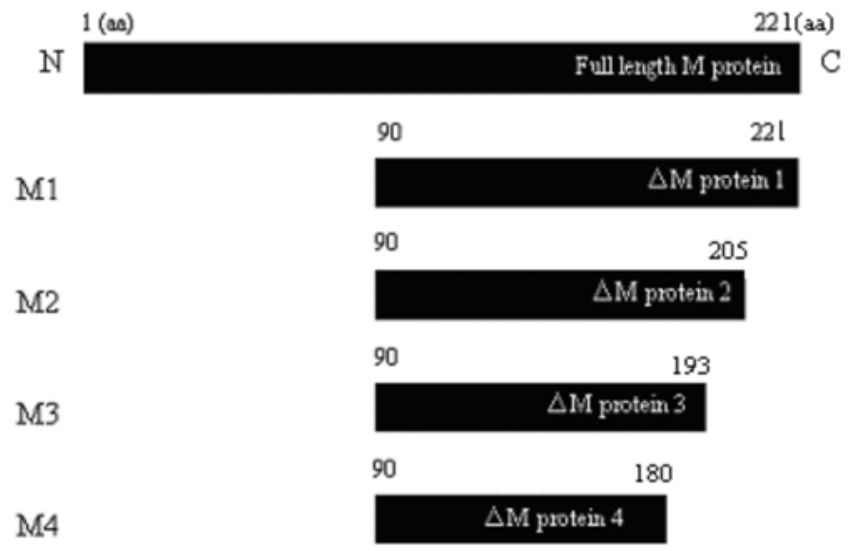

Fig. 1. Schematic description of SARS-CoV M protein sequential deletion mutations. Numbers above the bars indicated the first or the last amino acids in the deletion mutation. Mutant names are indicated in the left column.

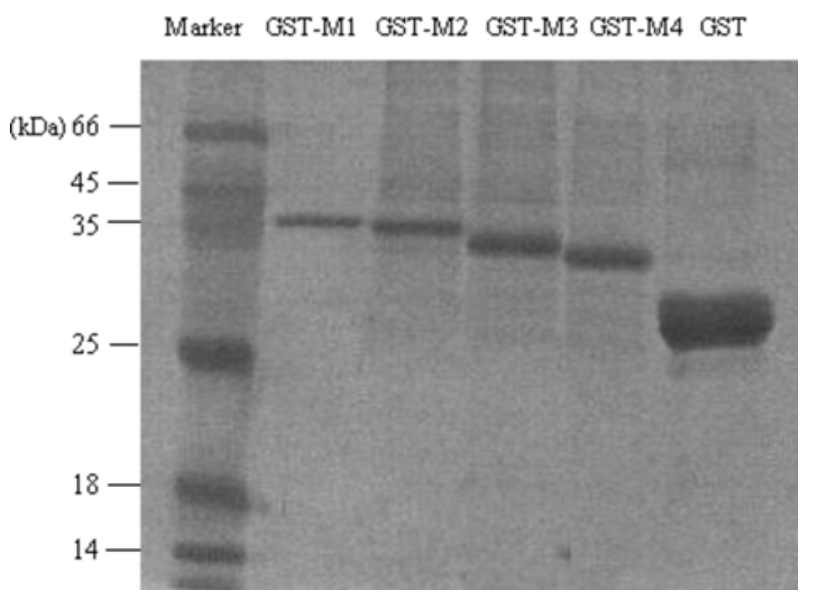

Fig. 2. SDS-PAGE analysis of various deletion mutants of GST$\mathrm{M}$ fusion proteins. Different truncated forms of GST-M proteins were expressed in E. Coli after $3 \mathrm{~h}$ induction with IPTG purified by Ni-NTA affinity column, fractionated by $12 \%$ SDS-PAGE and visualized by Coomassie Brilliant Blue staining.

appropriate volume of ECL solution (Amersham, Arlington Heights, USA) and reacted at room temperature for about $1 \mathrm{~min}$, then put onto a sensitization film for 1-3 min to develop and fix.

\section{Result}

Expression and purification of recombination proteins Different truncated forms of GST-M proteins (GST-M1, GSTM2, GST-M3 and GST-M4) with a C-terminal hexahistidinetag were expressed in BL21(DE3) and purified by Ni-NTA affinity column. After $3 \mathrm{~h}$ induction with IPTG at $37^{\circ} \mathrm{C}$, high level expression of recombination proteins were observed when compared with uninduced cells lysates. The His-tagged GST-fusion proteins were eluted with elution buffer $(20 \mathrm{mM}$ Tris- $\mathrm{HCl} \mathrm{pH}$ 7.9, $500 \mathrm{mM} \mathrm{NaCl}, 200 \mathrm{mM}$ Imidazole) and

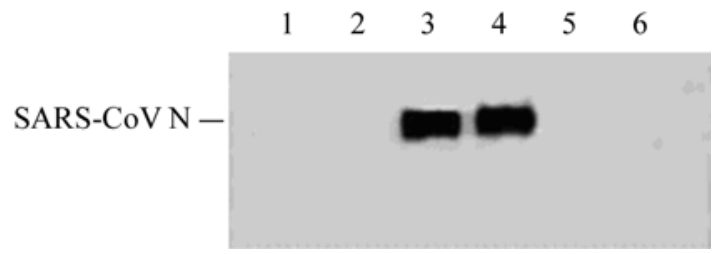

Fig. 3. GST pull-down assay. Approximately $1 \mu \mathrm{g}$ of GST or GST-M truncation purified proteins from bacterial expressed was immobilized on glutathione sepharose-4B beads and incubated with $0.1 \mu \mathrm{g}$ of bacterial expressed His-N protein. the bound proteins were eluted by heated at $100^{\circ} \mathrm{C}$ for $10 \mathrm{~min}$ and separated by $12 \%$ SDS-PAGE. Then detected by Western blotting using anti-SARS-CoV $\mathrm{N}$ protein rabbit antibody as the first antibody and peroxidase labeled goat anti-rabbit IgG as the second one. Lane 1: GST, N protein and GST resin; Lane 2: N protein and GST resin; Lane 3: GST-M1, N protein and GST resin; Lane 4: GST-M2, N protein and GST resin; Lane 5: GST$\mathrm{M} 3, \mathrm{~N}$ protein and GST resin; Lane 6: GST-M4, N protein and GST resin.

concentrated by dialysis against polyethyleneglycol 6000 resulting in single bands of expected molecular mass. These data demonstrated that the different truncated versions of GST-M proteins were successfully expressed in E. coli and purified to homogenity (Fig. 2).

The interaction of SARS-CoV $M$ protein with $\mathrm{N}$ protein We examined the possible interaction between SARS-CoV M and $\mathrm{N}$ proteins in vitro and identified the minimal sequence for this interaction. First, pull-down assay was carried out with GST-M1 (90-221) and N protein. The result demonstrated that $\mathrm{N}$ protein interacted with $\mathrm{N}$-termini truncated $\mathrm{M}$ protein in GST-fused form. As a negative control, $\mathrm{N}$ protein bound neither GST nor GST resin. This result was in consentience with previous report by $\mathrm{He}$ et al. (2004) and demonstrated that the binding region didn't lie in the N-terminal of M protein. In order to identify the M-N binding domain of SARS-CoV, we employed GST pull-down with a set of C-terminal truncated forms of GST-M proteins with $\mathrm{N}$ protein. We found that the deletion mutant GST-M2 (90-205) bound N protein, while other mutant proteins GST-M3 (90-193), GST-M4 (90-180) did not bind. The analysis of GST pull-down results showed that the binding region occurred in the C-terminal of $\mathrm{M}$ protein and a region composed of 12 amino acids from 195 to 206 has been found to be the minimal sequence for the interaction between SARS-CoV M protein and $\mathrm{N}$ protein as shown in Fig. 3.

\section{Discussion}

In our research we employed GST pull-down assay to investigate the molecular interaction between the SARS-CoV $\mathrm{M}$ and $\mathrm{N}$ proteins and confirmed it did take place in vitro. Furthermore, series of truncated forms of GST-fused M 


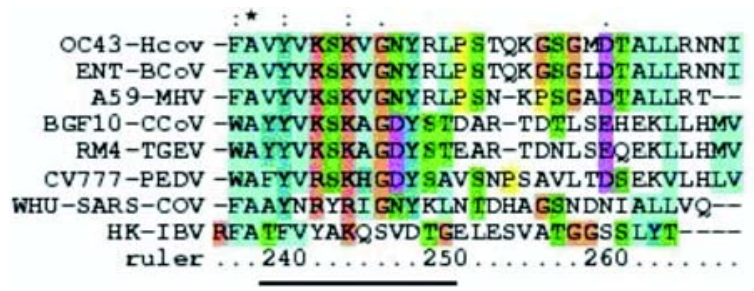

230

230

228

262

262

226

221

223

Fig. 4. Deduced amino acid sequence alignment for the $M$ proteins of selected coronavirus isolates. The sequence alignment was generated by Clustal X (1.83) multiple sequence alignment software and the interaction site of SARS-CoV M protein was indicated on the bottom line. GenBank accession numbers for $M$ protein sequences of selected isolated are as follow: SARS-CoV WHU (SARS coronavirus, strain WHU), AY39480; OC43-HcoV (human coronavirus, strain OC43), NP 937953; ENT-BcoV (bovine coronavirus, isolate BCoV-ENT), NP 150082; A59MHV (murine hepatitis virus, strain MHV-A59), NP 045301; BGF10-CcoV (canine coronavirus, strain BGF10), CV777-PEDV (porcine epidemic diarrhea virus, strain CV777), NP 598313; (transmissible gastroenteritis coronavirus, strain RM4), A36607; HK-IBV(infectious bronchitis virus, strain HK), AAV28726.

proteins were expressed in E. coli and purified by Ni-NTA affinity column. Using GST pull-down assay, we found that a region in the carboxy terminal of $\mathrm{M}$ protein appears to be vital for M-N interaction and the interaction site has been identified to the residues 194 to 205 of the SARS-CoV M protein. An early study by Sturman et al (1980) was the first to show a direct and temperature-dependent association between the $\mathrm{M}$ and $\mathrm{N}$ proteins purified from MHV. Nearly two decades later, Lili et al. used targeted recombination with MHV for the systematic genetic analysis of coronavirus M-N proteins interaction and they found residues 201 to 224 of the MHV M protein were the contributory parts for the interaction of M-N protein (Lili et al., 2002). For the TGEV, Escors et al defined an interaction between the carboxy terminus of in vitrotranslated $\mathrm{M}$ protein and purified viral nucleocapsid, Using a combination of $\mathrm{M}$ protein mutagenesis, inhibition by antibodies of defined specificity, and peptide competition, they were able to map this interaction to residues 233 to $257 \mathrm{aa}$ of the M protein (Escors et al., 2001). Our result corresponds to roughly homologous segments of residues 233 to 257aa and 201 to 224aa of the TGEV M and MHV M proteins respectively. Alignment of the SARS-CoV M protein with $M$ proteins from other member of coronaviridea family showed that the binding region (194-205 aa) was one of the highly conserved regions in the coronavirus M protein (Fig. 4) and these homologous regions showed highly polar and hydrophilic properties.

The M-N interaction appears to be an essential process for coronaviral assembly because the coronaviruses differ from other enveloped viruses such as paramyxoviruses and rhabdoviruses, which own the structural matrix protein that commonly links the envelope to the nuclecapsid. Thereby, it can be envisaged that replacing the matrix protein in the role of core stabilization through nucleocapsid binding appears to be one of the functions of the coronavirus $M$ protein. A recent study on MHV suggests a multiple binding role for the nucleocapsid protein in virus assembly and morphogenesis and the $\mathrm{M}$ protein has also been found to have a viral RNA binding site that interacts with the RNA packaging signal (Narayanan et al., 2003). Through the complex of viral RNA, nucleocapsid protein, and $M$ protein, it is evident that the assembly of a mature coronavirus is a multi-step process involving in protein-protein and protein-RNA interactions. Although SARS-CoV M and N proteins share low homology with others in the coronaviral family, our current study reveals that the M-N interaction exists in SARS-CoV as it does in other members of the Coronaviridae family, reinforcing a notion that $\mathrm{M}-\mathrm{N}$ interaction forms the crucial structure for coronaviruses. However, the intermolecular interaction of SARS-CoV $\mathrm{M}$ and $\mathrm{N}$ protein remains unclear. Recently He et al employed the mammalian two-hybrid system to investigate the possible interaction between SARS-CoV $\mathrm{M}$ and $\mathrm{N}$ proteins and they found that interaction takes place in vivo and identified that a stretch of amino acids 168 to 208 which includes SR rich domain in the $\mathrm{N}$ protein may be critical for such protein-protein interactions. The same region has also been found to be indispensable for multimerization of the $\mathrm{N}$ proteins (He et al., 2004). In other words, it can be assumed that this region may not serve as contact site for either $\mathrm{N}-\mathrm{N}$ or $\mathrm{N}-\mathrm{M}$ interaction. Overall, the SARS-CoV N protein is highly basic but there is concentration of acidic residues in its carboxy-terminal domain; this general pattern is common to all coronaviruses N proteins (Laude and Masters, 1995). Residues 195 to 206 of the SARS-CoV M protein concentrate with basic amino acids. We hypothesize that the residues 195 to 206 of the SARS-CoV M protein are electrostatically linked with one or more glutamate residues in carboxyterminal domain of $\mathrm{N}$ protein. To test this, we are currently carrying out a comprehensive mutagenesis of the charged residues of the carboxy terminus of the $\mathrm{N}$ protein. In conclusion, our data has shown that the SARS-CoV M and $\mathrm{N}$ proteins can interact with each other in vitro and the minimal sequence for the interaction has been mapped to the residues (194-205aa) in SARS-CoV M protein. This region of the M protein appears to be important for one of the critical steps of viral assembly and maturation process. Our work would help shed light on the molecular mechanism of the virus assembly and provide valuable information, which regards to rationalize the future anti-viral strategies.

Acknowledgment We thank Dr Ying Zhu (College of Life Science, Wuhan University, Wuhan, China) for providing pGEM $^{\circledR}$-T-M

\section{References}

Corse, E. and Machamaer, C. E. (2000) Infectious bronchitis virus 
E protein is targeted to the Golgi complex and directs release of virus-like particles. $J$. Virol. 74, 4319-4326.

de Haan, C. A., Kuo, L., Masters, P. S., Vennema, H. and Rottier, P. J. (1998) Coronavirus particle assembly: primary structure requirements of the membrane protein. J. Virol. 72, 6838-6850.

de Haan, C. A., Vennema, H. and Rottier, P. J. (2000) Assembly of the coronavirus envelope: homotypic interactions between the M proteins. J. Virol. 74, 4967-4978.

Drosten, C., Gunther, S., Preiser, W., vander Werf, S., Brodt, H. R., Becker, S., Rabenau, H., Panning, M., Kolesnikova, L., Fouchier, R. A., Berger, A., Burguiere, A. M., Cinatl, J., Eickmann, M., Escriou, N., Grywna, K., Kramme, S., Manuguerra, J. C., Muller, S., Rickerts, V., Sturmer, M., Vieth, S., Klenk, H. D., Osterhaus, A. D., Schmitz, H. and Doerr, H. W. (2003) Identification of a novel coronavirus in patientswith severe acute respiratory syndrome. N. Engl. J. Med. 348, 19671976.

Escors, D., Ortego, J. and Enjuanes, L. (2001) The membrane M protein of the transmissible gastroenteritis coronavirus binds to the internal core through the carboxy-terminus. Adv. Exp. Med. Biol. 494, 589-593.

He, R., Dobie, F., Ballantine, M., Leeson, A., Li, Y., Bastien, N., Cutts, T., Andonov, A., Cao, J., Booth, T., Plummer, F. A., Tyler, S., Baker, L. and Li, X. (2004) Analysis of multimerization of SARS-CoV nucleocapsid protein. Biochem. Biophys. Res. Commun. 316, 476-483.

He. R. and Leeson, A. (2004) Characterization of protein-protein interactions between the nucleocapsid protein and membrane protein of the SARS coronavirus. Virus Res. 105, 121-125.

Holmes, K. V. (2001) Coronaviruses; in Field's Virology, Knipe, D. M. and Howley, P. M. (eds.), pp. 1187-1203, Lippincott, Williams \& Wilkins, Philadelphia. USA.

Hiscox, J. A., Wurm, T., Wilson, L., Britton, P., Cavanagh, D. and Brooks, G. (2001) The coronavirus infectious bronchitis virus nucleoprotein localizes to the nucleolus. J. Viro. 75, 506-512.

Ksiazek, T. G., Erdman, D., Goldsmith, C. S., Zaki, S. R., Peret, T., Emery, S., Tong, S., Urbani, C., Comer, J. A., Lim, W., Rollin, P. E., Dowell, S. F., Ling, A. E., Humphrey, C. D., Shieh, W. J., Guarner, J., Paddock, C. D., Rota, P., Fields, B., DeRisi, J., Yang, J. Y., Cox, N., Hughes, J. M., LeDuc, J. W., Bellini, W. J. and Anderson, L. J. (2003) A novel coronavirus associated with severe acute respiratory syndrome. N. Engl. J. Med. 348, 1953-1966.

Kuo, L. and Masters, P. S. (2002) Genetic evidence for a structural interaction between the carboxy termini of the membrane and nucleocapsid proteins of mouse hepatitis virus. J. Viro. 76, 4987-4999.

Lee, N., Hui, D., Wu, A., Chan, P., Cameron, P., Joynt, G. M., Ahuja, A., Yung, M. Y., Leung, C. B., To, K. F., Lui, S. F., Szeto, C. C., Chung, S. and Sung, J. J. (2003) A major outbreak of severe acute respiratory syndrome in Hong Kong. N. Engl. J. Med. 348, 1986-1994.

Lili, K. and Masters, P. S. (2002) Genetic evidence for a structural interaction between the carboxy termini of the membrane and nucleocapsid proteins of mouse hepatitis virus. J. Virol. 76, 4987-4999.

Marra, M. A., Jones, S. J., Astell, C. R., Holt, R. A., BrooksWilson, A., Butterfield, Y. S., Khattra, J., Asano, J. K., Barber, S. A., Chan, S. Y., Cloutier, A., Coughlin, S. M., Freeman, D., Girn, N., Griffith, O. L., Leach, S. R., Mayo, M., McDonald, H., Montgomery, S. B., Pandoh, P. K., Petrescu, A. S., Robertson, A. G., Schein, J. E., Siddiqui, A., Smailus, D. E., Stott, J. M., Yang, G. S., Plummer, F., Andonov, A., Artsob, H., Bastien, N., Bernard, K., Booth, T. F., Bowness, D., Czub, M., Drebot, M., Fernando, L., Flick, R., Garbutt, M., Gray, M., Grolla, A., Jones, S., Feldmann, H., Meyers, A., Kabani, A., Li, Y., Normand, S., Stroher, U., Tipples, G. A., Tyler, S., Vogrig, R., Ward, D., Watson, B., Brunham, R. C., Krajden, M., Petric, M., Skowronski, D. M., Upton, C. and Roper, R. L. (2003) The Genome sequence of the SARS-associated coronavirus. Science 300, 1399-1404.

Narayanan, K., Chen, C. J., Maeda, J. and Makino, S. (2003) Nucleocapsid-independent specific viral RNA packaging via viral envelope protein and viral RNA signal. J. Virol. 77, 29222927.

Narayanan, K. and Makino, S. (2001) Cooperation of an RNA packaging signal and a viral envelopeprotein in coronavirus RNA packaging. J. Virol. 75, 9059-9067.

Riley, S., Fraser, C., Donnelly, C. A., Ghani, A. C., Abu-Raddad, L. J., Hedley, A. J., Leung, G. M., Ho, L. M., Lam, T. H., Thach, T. Q., Chau, P., Chan, K. P., Lo, S. V., Leung, P. Y., Tsang, T., Ho, W., Lee, K. H., Lau, E. M., Ferguson, N. M. and Anderson, R. M. (2003) Transmission dynamics of the etiological agent of SARS in Hong Kong: impact of public health interventions. Science 300, 1961-1966.

Rota, P. A., Oberste, M. S., Monroe, S. S., Nix, W. A., Campagnoli, R., Icenogle, J. P., Peneranda, S., Bankamp, B., Maher, K., Chen, M. H., Tong, S., Tamin, A., Lowe, L., Frace, M., DeRisi, J. L., Chen, Q., Wang, D., Erdman, D. D., Peret, T. C., Burns, C., Kziazek, T. G., Rollin, P. E., Sanchez, A., Liffick, S., Holloway, B., Limor, J., McCaustland, K., OlsenRasmussen, M., Fouchier, R., Gunther, S., Osterhaus, A. D., Drosten, C., Pallansch, M. A., Anderson, L. J. and Bellini, W. J. (2003) Characterization of a novel coronavirus associated with severe acute respiratory science. Science 300, 1394-1399.

Rottier, P. J. M. (1995) The coronavirus membrane protein; in The Coronaviridae, Siddell, S. G. (Ed.), pp. 115-139, Plenum Press, New York, USA

Sturman, L. S., Holmes, K. V. and Behnke, J. (1980) Isolation of coronavirus envelope glycoproteins and interaction with the viral nucleocapsid. J. Virol. 33, 449-462.

Timani, K. A., Ye, L., Ye, L. B., Zhu, Y., Wu, Z. H. and Gong, Z. J (2004) Cloning, sequencing, expression, and purification of SARS-associated coronavirus nucleocapsid protein forserodiagnosis of SARS. J. Clin. Virol. 30, 309-312 